\title{
POLOŽAJ DOBROVOLJACA IZ ISELJENIŠTVA U SRBIJANSKOJ VOJSCI PREMA DOKUMENTIMA IZ OSTAVŠTINE DR. ANTE TRUMBIĆA (1914. - 1918.)
}

Ivan HRSTIĆ

Institut društvenih znanosti Ivo Pilar, Zagreb

UDK: 355.087.2-054.7(497.11)"1914/1918"

Izvorni znanstveni rad

Primlieno: 1. 9. 2010.

U radu se, prema dokumentaciii koja se nalazi u arhivskoi ostarštini dr. Ante Trumbića u Hrvatskoj akademiii znanosti i umjetnosti u Zagrebu, analizira dobrovoljački pokret među hrvatskim iseljenicima za srbijansku vojsku u Prvom svjetskom ratu te istražuje nịhov položaj u nioj. Dobrovoljci su se javljali najviše iz Sjeverne i Južne Amerike, Australije te Novoga Zelanda, a aktivno su pristupili vojsci na Solunskom bojištu. Srbijanska vojska ih je po dolasku uključivala u već postojeće postrojbe, unatoč zalaganju Jugoslavenskog odbora da se osnuje posebna postrojba, koja bi simbolizirala političku želiu južnih Slavena iz Austro-Ugarske Monarhije za ujedinjenjem s Kraljevinom Srbijom. Srbijanska vlada i vojska vodile su dvostruku politiku prema dobrovoljcima. Javno su proklamirali ravnopravnost $i$ jednakost svih vojnika i dobrovoljaca te izdavali zapovijedi u tom smislu, a u isto vrijeme časnicima upućivanima $u$ iseljeništvo na agitaciju davali su tajne upute da od Hrvata prave "dobre Srbe". Jugoslavenski odbor nisu upućivali u aktivnosti oko prikuplianja dobrovoljaca i njihova djelovanja u vojsci, gdje su oni često bili zlostavliani. Kada bi se dobrovoljci pobunili, bili bi zatvoreni, a nakon završetka rata velik broj ih se vratio u zemlje iz kojih su došli.

Ključne riječi: iseljeništvo, Prvi svjetski rat, dobrovoljački pokret, Jugoslavenski odbor, srbijanska vojska 
Od kraja 19. stoljeća do početka Prvog svjetskog rata iz Austro-Ugarske Monarhije iselilo je oko pola milijuna Hrvata. Razlozi za iseljavanje najčešće su bili ekonomske prirode, a iseljenici su bili pretežno neobrazovani mladi muškarci koji su iseljavali u prekomorske zemlje: Sjevernu i Južnu Ameriku, Australiju te Novi Zeland (Holjevac, 1968., 32-33). Nakon početka Prvog svjetskog rata našli su se kao austrougarski državljani u nezavidnom položaju. Službene vlasti pozivale su ih na povratak i stupanje u austrougarsku vojsku, dok su projugoslavenski orijentirani pojedinci i organizacije, kasnije predvođeni Jugoslavenskim odborom, agitirali protiv toga. U posebno teškoj situaciji našli su se iseljenici iz Monarhije nastanjeni u državama koje su bile dio saveza sila Antante, koje su nakon početka rata naredile zatvaranje neprijateljskih državljana. U isto vrijeme, neutralne zemlje nastojale su što više očuvati svoju neutralnost te ograničiti i neutralizirati djelovanje zastupnika bilo koje od zaraćenih strana (Čizmić, 1974., 79-81).

U tim uvjetima Jugoslavenski je odbor u suradnji sa srbijanskom vladom pokrenuo inicijativu oko prikupljanja hrvatskih, slovenskih i srpskih iseljenika iz Austro-Ugarske kao dobrovoljaca za srbijansku vojsku, odnosno Jadransku legiju, koja će biti posebna postrojba u njezinu sklopu. Oko toga ubrzo je došlo do nesuglasica između Odbora i srbijanske vlade. Odbor se zalagao za osnivanje posebne postrojbe, koja bi politički simbolizirala odlučnost južnoslavenskih naroda unutar Austro-Ugarske za izlazak iz te države, dok je srbijanska vlada htjela dobrovoljce uključiti u postojeće postrojbe srbijanske vojske (Čizmić, 1974., 83-85, 213; Paulova, 1925., 34-35).

Velik broj dokumenata koji mogu poslužiti boljem proučavanju cjelokupnoga dobrovoljačkog pokreta te primanja i položaja hrvatskih iseljenika u srbijanskoj vojsci može se pronaći u arhivskoj ostavštini dr. Ante Trumbića, predsjednika Jugoslavenskog odbora, koji se čuva u arhivu Hrvatske akademije znanosti i umjetnosti u Zagrebu. ${ }^{1}$

\section{PREGLED RAZVOJA DOBROVOLJAČKOGA POKRETA}

Kod istaknutih hrvatskih iseljenika okupljenih u Rimu, koji su kasnije osnovali Jugoslavenski odbor, javila se ideja o prikupljanju dobrovoljaca za srbijansku vojsku među južnoslavenskim iseljenicima iz Austro-Ugarske. Pokretač ideje bio je dr. Ljubo Leontić, ${ }^{2}$ a odluku o osnivanju Jadranske legije donijeli su 24. siječnja 1915. 3 Odmah su naglasili da su svjesni kako Legija neće biti od presudne vojne pomoći srbijanskoj vojsci, ali će simbolizirati odlučnost Južnih Slavena unutar Monarhije za izlaskom iz njezinih okvira i ujedinjenjem sa Srbijom. Odluku o osnivanju Legije prenijeli su Nikoli Pašiću, predsjed- 
DRUŠ. ISTRAŽ. ZAGREB GOD. 21 (2012), BR. 1 (115)

STR. $239-258$

HRSTIĆ, I.: POLOŽAJ DOBROVOLJACA niku srbijanske vlade, koji je na to odgovorio tek nakon dva mjeseca s upitima o troškovima Legije i zapovijedanja nad njom.

Srbijanska vlada bila je prilično oprezna s idejom osnivanja slične postrojbe, jer bi na taj način došli u sukob s Italijom, koja je polagala pravo na istočnu jadransku obalu te su htjeli pričekati i vidjeti tijek rata, pa tek onda jasnije izaći sa svojim namjerama. Posebnom postrojbom unutar svoje vojske slabila bi se i ideja o misiji Srbije kao jugoslavenskoga Pijemonta, koja će osloboditi potlačene južnoslavenske narode unutar Monarhije, a postojala je i mogućnost da takva postrojba nakon rata postane bitan čimbenik prilikom uređenja odnosa unutar zajedničke države. Također je bitno i da u to vrijeme srbijanska vojska još uvijek nije bila doživjela velikih vojnih poraza i njezini vodeći krugovi nisu osjećali potrebu za popunom ljudstva kadrom iz inozemstva. No, unatoč odugovlačenju srbijanske vlade, dobrovoljački pokret počeo je među iseljenicima davati rezultate. Stoga je Jugoslavenski odbor odlučio u lipnju 1915. poslati u agitaciju u Sjevernu Ameriku Milana Marjanovića, ${ }^{4}$ a u Južnu dr. Miću Mičića. ${ }^{5}$ Za to vrijeme dobrovoljački pokret razvio se i među zarobljenim austrougarskim vojnicima u Rusiji (Čizmić, 1974., 84; Potočnjak, 1926., 90). ${ }^{6}$

Tijekom ljeta 1915. dr. Franko Potočnjak ${ }^{7}$ boravio je u Nišu te se oko dobrovoljaca iz iseljeništva dogovorio s Nikolom Pašićem da će srbijanska vlada snositi troškove prijevoza dobrovoljaca do Soluna, a po njihovu dolasku osnovat će posebnu postrojbu pod zapovjedništvom Milana Pribićevića (Potočnjak, 1919., 18). ${ }^{8}$ Ipak, do konačne pismene vladine potvrde nije došlo, a potporu ideji nije dala ni engleska vlada zbog protivljenja SAD-a novačenju na svojem teritoriju, a ovo zbog proglašene neutralnosti.

Tijekom 1916. godine dobrovoljački pokret dobio je nov zamah zbog katastrofe srbijanske vojske potkraj 1915. i velikih gubitaka nakon austrougarske ofanzive te povlačenja preko Albanije. Na mogućnost angažiranja dobrovoljaca otada se gledalo kao i na konkretnu vojnu pomoć, a ne samo simboličnu i političku. Srbijanska vlada čak je svakom dobrovoljcu koji će služiti kao borac obećala 5 hektara zemlje, a neborcu 3 hektara. ${ }^{9}$ Probleme jačoj akciji i agitaciji stvarao je i dalje otpor SAD-a zbog neutralnosti te Engleske oko prijevoza dobrovoljaca u Europu.

\section{Dobrovoljački pokret u Južnoj Americi}

Iseljenici iz Austro-Ugarske u Južnoj Americi bili su većinom Hrvati, podrijetlom iz Dalmacije, među kojima je bila prilično razvijena jugoslavenska ideja. Već u kolovozu 1914. u Buenos Airesu, u listu Hrvatska straža, izdali su manifest kojim su pozvali sve Slavene iz Monarhije da joj se odupru i organiziraju 
DRUŠ. ISTRAŽ. ZAGREB GOD. 21 (2012) BR. 1 (115)

STR. $239-258$

HRSTIĆ, I.: POLOŽAJ DOBROVOLJACA. ske vojske (Kolin, 1920., 13). Na "velikom zboru Jugoslavena u Južnoj Americi", održanom u Antofagasti 23. siječnja 1916., osnovali su Jugoslavensku narodnu obranu, koja je preuzela na sebe sve akcije oko prikupljanja dobrovoljaca u Južnoj Americi, financiranja rada Jugoslavenskog odbora, pomoći srpskom $\mathrm{Cr}$ venom krstu i slično. Posebnu agitaciju oko dobrovoljaca u Južnoj Americi provodili su dr. Mičić i predstavnik Jugoslavenske ujedinjene omladine, dr. Ljubo Leontić. Leontić je tražio jaču akciju, pa je zbog toga bio u sukobu s Jugoslavenskim odborom, koji je najprije htio riješiti pitanje Jadranske legije sa srbijanskom vladom (Leontić, 1966., 243-259). ${ }^{10}$ Ondje su čak nabavljena i dva parobroda. Njihovi su kapetani bili spremni prebaciti dobrovoljce $\mathrm{u}$ Europu, ali to nije dopuštala engleska vlada. ${ }^{11}$

Srbijanska vlada pokrenula je u srpnju 1916. ponovno pitanje odobravanja kredita za prijevoz dobrovoljaca u Europu kod francuske vlade, koja ga je u listopadu iste godine konačno i odobrila. No srbijanska vlada o tome nije obavijestila Jugoslavenski odbor, koji je taj podatak saznao tek u veljači 1917. Za to vrijeme vlada je odlučila da se dobrovoljci prije odlaska u Solun okupljaju u Bizerti te poslala Milana Pribićevića u Sjevernu, a Špiru Poznanovića u Južnu Ameriku na prikupljanje dobrovoljaca. Iako je tek naknadno saznao za tu inicijativu, Odbor ju je podržao, kao i srbijanske izaslanike u njihovu radu, pogotovo Pribićevića.

Otvoreni spor između srbijanske vlade i Jugoslavenskog odbora konačno je izbio oko neovlaštena proglasa članova Odbora dr. Hinka Hinkovića i dr. Josipa Jedlowskog u studenom 1916. Oni su, uime Odbora i s krivotvorenim Trumbićevim potpisom, u proglasu pozvali sve dobrovoljce na okupljanje i dolazak u Europu te stupanje $u$ srbijansku vojsku, što nije bilo u skladu sa stajalištem Odbora, koji je htio posebnu postrojbu. ${ }^{12}$ Poziv je stigao u Južnu Ameriku na početku siječnja 1917. i urodio je plodom. Dobrovoljci su bili spremni krenuti na put za Bizertu 25. veljače 1917., ali je Jugoslavenski odbor zaustavio daljnje okupljanje i polazak na put.

Ukupni broj dobrovoljaca u Južnoj Americi nije bio velik i oni ne bi predstavljali bitnu vojnu pomoć na bojištu, ali su upravo ti pojedinci bili nositelji projugoslavenske iseljeničke zajednice ondje te su ujedno bili i glavni financijeri Jugoslavenskog odbora. Njihovim dolaskom na bojište Odbor bi izgubio novčanu neovisnost u svojem radu, pa je, uz neriješeno pitanje osnutka Jadranske legije, to bio dodatni razlog zbog kojeg je Miće Mičić predložio Odboru da obustavi njihov dolazak. ${ }^{13}$ Širi iseljenički krugovi tek su tada upoznati s razilaženjem stavova između Odbora i srbijanske vlade oko dobrovoljaca. Stali su na stranu Jugoslavenskog odbora i odustali od dolaska u Europu. 
DRUŠ. ISTRAŽ. ZAGREB GOD. 21 (2012), BR. 1 (115)

STR. 239-258

HRSTIĆ, I.: POLOŽAJ DOBROVOLJACA
Jugoslavenski odbor je na sjednici održanoj u Nici 10. veljače 1917. pokrenuo inicijativu o prikupljanju novaca u Južnoj Americi za zrakoplovnu eskadrilu u zamjenu za slanje dobrovoljaca. No unatoč prikupljenom novcu, ni to se nije ostvarilo (Kolin, 1920., 22). ${ }^{14} \mathrm{~S}$ iste sjednice poslana je srbijanskoj vladi i spomenica o dobrovoljačkom pitanju, a tek u odgovoru na nju Odbor je saznao za odobrene kredite francuske vlade za prijevoz dobrovoljaca. Na tu vijest Odbor je opet zasjedao, ovaj put u Cannesu, u veljači 1917., i ponovio zahtjeve vezane uz osnivanje Legije. ${ }^{15}$ Obustavljanje slanja dobrovoljaca iz Južne Amerike i čvrst stav da žele osnivanje posebne dobrovoljačke postrojbe dodatno je zaoštrio odnose sa srbijanskom vladom.

Zanimljivo je da je cijelo to vrijeme na snazi bila zapovijed srbijanskoga vojnog ministra, koja je austrougarskim podanicima zabranjivala aktivno služenje u borbenim postrojbama srbijanske vojske, što je tražio i Jugoslavenski odbor, da se austrougarske vlasti ne bi osvećivale obiteljima dobrovoljaca. ${ }^{16}$ Ipak, iz dokumenata se vidi da se toga u stvarnosti nije pridržavala ni srbijanska vojska ni Jugoslavenski odbor, jer su dobrovoljci na prijavnicama za Jadransku legiju ispunjavali žele li služiti kao borci ili kao neborci. ${ }^{17}$

Špiro Poznanović nastavio je s agitacijom za srbijansku vojsku u Južnoj Americi i nakon negativnog odgovora Jugoslavenskog odbora o slanju dobrovoljaca te je imao uspjeha kod Srba i Crnogoraca, ali ne i kod najbrojnijih iseljenika - Hrvata. Opet je pozvao na ukrcavanje dobrovoljaca u Čileu 21. ožujka 1917., na što mu je dr. Ljubo Leontić odgovorio kako će oni raditi samo po uputama Jugoslavenskog odbora, pa na kraju do većeg odlaska hrvatskih dobrovoljaca iz Južne Amerike nikada nije ni došlo (Paulova, 1925., 263-264).

\section{Dobrovoljački pokret u SAD-U}

Iz SAD-a je još 1914. godine otišlo oko 4000 dobrovoljaca, a 1915. još 1900 (Čizmić, 1974., 79-81). To su bili pretežno Srbi i Crnogorci, a među njima i poneki Hrvat. Sve se odvijalo više na individualnoj razini, bez nekoga organiziranog pokreta te bez utjecaja Jugoslavenskog odbora. Potkraj 1915. dobrovoljci su se gotovo prestali javljati, najviše pod utjecajem odjeka katastrofe srbijanske vojske. Brojni povratnici s bojišta i dezerteri donosili su strašne priče o ratu te na taj način dodatno obeshrabrivali možebitne dobrovoljce. ${ }^{18}$

Agitaciju za Jadransku legiju u Sjevernoj Americi uime Jugoslavenskog odbora još je od listopada 1915. provodio Milan Marjanović (Cizmić, 1974., 85). Marjanović je bio najzaslužniji i za organizaciju drugoga velikog jugoslavenskog zbora, koji se održao u Pittsburghu 29. i 30. studenog 1916.19 Na tom zboru 
DRUŠ. ISTRAŽ. ZAGREB GOD. 21 (2012)

BR. 1 (115)

STR. $239-258$

HRSTIĆ, I.:

POLOŽAJ

DOBROVOLJACA. osnovano je Jugoslavensko narodno vijeće, koje je ujedinilo sve iseljeničke organizacije jugoslavenske orijentacije, a tom prilikom ujedinili su se i iseljenički hrvatski, srpski i slovenski sokoli u jedinstveni Jugoslavenski sokolski savez. Predsjednik Saveza postao je Milan Marjanović, a "sokoli" su formalno preuzeli na sebe daljnje okupljanje dobrovoljaca te uveli $u$ svoju obuku vježbe s oružjem (Čizmić, 1974., 215).20 No u stvarnosti je od kraja 1916. sve ovlasti oko prikupljanja dobrovoljaca za srbijansku vojsku u Sjevernoj Americi preuzeo Milan Pribićević. Pošto ni dalje nije među Hrvatima bilo prevelikog odaziva za dobrovoljački pokret, Marjanović je 23. lipnja 1917. uputio proglas na hitno stupanje u vojsku i raspustio sokolsku organizaciju. ${ }^{21}$

Zanimljivo je da je Milan Pribićević u Sjevernoj Americi imao jaču potporu Jugoslavenskog odbora u prikupljanju dobrovoljaca za srbijansku vojsku od Poznanovića u Južnoj. To se djelomično može objasniti njegovim utjecajem koji je stekao prije Prvog svjetskog rata, jer je još 1904. kao časnik austrougarske vojske prešao u Srbiju, a 1907. napisao Štatut revolucionarne organizacije Južnih Slavena, koji je u osnovi plan za rušenje Monarhije. Čelnici Jugoslavenskog odbora vjerovali su da on, kao prečanski Srbin, dijeli s njima viziju buduće zajedničke države i davali su mu jaču podršku. No glavni razlog otpora, što ga je Odbor pružao okupljanju dobrovoljaca u Južnoj Americi, leži u tome što su oni novčano održavali njegov rad, dok iseljenici u Sjevernoj Americi nisu bili toliko organizirani.

Uz neutralnost SAD-a i nemogućnost organiziranja prijevoza dobrovoljaca u Europu, velike probleme njihovu prikupljanju u SAD-u činile su i podjele unutar srpske iseljeničke zajednice, odnosno djelovanje počasnoga srpskog poslanika u New Yorku, Mihajla Pupina, koji je smatrao da je potrebnije slati materijalnu pomoć nego ljude. U isto vrijeme njegovi su suradnici svojim velikosrpskim izjavama i tekstovima budili nepovjerenje Hrvata i Slovenaca prema budućnosti i zajedničkoj državi sa Srbima. ${ }^{22}$

Dobrovoljci su zbog neutralnosti SAD-a prikupljani kao radnici, a zatim su putovali u Camp Lévis u Kanadi, gdje se nalazio sabirni centar. Ukupno gledajući, dobrovoljački je pokret i u SAD-u doživio neuspjeh. Za cijelo vrijeme rata prijavilo se oko 10000 dobrovoljaca, od čega daleko najviše Srba i Crnogoraca, što je i razumljivo, ali kojih je bilo najmanje među južnoslavenskim iseljenicima. Primjerice, od 3000 dobrovoljaca, koje je Pribićević otputio na bojište dok je bio na položaju šefa misije za skupljanje dobrovoljaca među Južnim Slavenima u Sjevernoj Americi, bilo je samo oko 200 Hrvata i Slovenaca. 23 


\section{Dobrovoljački pokret u Australiji i Novom Zelandu}

U dobrovoljačkom pokretu bili su aktivni i hrvatski iseljenici u Australiji i Novom Zelandu. Nakon početka Prvog svjetskog rata australske vlasti popisale su sve useljenike podrijetlom iz neprijateljskih država. Fotografirali su ih, uzeli im otiske prstiju i zapisali fizičke karakteristike. U rujnu 1914. mnoge su zatvorili u zarobljeničke logore, od kojih se najveći nalazio $u$ Liverpoolu, u saveznoj državi Novi Južni Wales. Do kolovoza 1915. ondje je bilo zatvoreno 1100 civila, pretežno Nijemaca, a ukupno $\mathrm{u}$ australskim logorima tijekom Prvog svjetskog rata bilo je zarobljeno 6890 neprijateljskih državljana, od kojih nekoliko stotina Hrvata. Oni koji nisu bili internirani u logore morali su se jednom tjedno javljati lokalnoj policijskoj stanici te dojavljivati eventualne promjene adrese boravišta. Njih je ukupno bilo 4260, a dosadašnja istraživanja nisu otkrila koliko je među njima bilo Hrvata (Stenning, 1995., 1, 8).

Nakon izbijanja rata iseljenici u Aucklandu, najvećem gradu na Novom Zelandu, pod vodstvom Jurja L. Skansija, organizirali su 31. srpnja 1914. prosvjed pred austrougarskim veleposlanstvom i uništili zastavu Monarhije (Čizmić, 1981., 73-74). Ubrzo su počeli prikupljati novac za pomoć Srbiji, a u listu Zora objašnjavali su ondašnjoj javnosti njihovo viđenje sukoba u Europi i na Balkanu te pozivali iseljene Južne Slavene da pomognu Srbiji. U svakodnevnom životu imali su slične probleme kao i Hrvati u Australiji. Manji broj bio je interniran, a bila je osnovana i vladina komisija, koja je 21. kolovoza 1916. utvrdila da su useljeni austrougarski državljani najvećim brojem podrijetlom iz Dalmacije i da ne predstavljaju nikakvu opasnost za državnu sigurnost, jer su lojalni građani Novoga Zelanda (Čizmić, 1981., 90-95).

Kao i u Južnoj i Sjevernoj Americi hrvatski iseljenici u Australiji i na Novom Zelandu počeli su se ubrzo dobrovoljno prijavljivati za vojnu službu. Prvo su se javili oni koji su imali australsko ili novozelandsko državljanstvo za služenje u australsko-novozelandskoj vojsci. Na Galipolju te u Francuskoj i Belgiji borilo se najmanje 78 Hrvata koji su zadržali hrvatski oblik prezimena (Šutalo, 2004., 197, 201). No i oni su ubrzo na bojištu mogli služiti samo u pozadini, jer se jedan novozelandski vojnik, podrijetlom Nijemac, predao njemačkim snagama i odao savezničke položaje, što je, ubuduće, na sve "strance" u vojsci bacilo sumnju. ${ }^{24}$

Godine 1917. osnovana je u Australiji posebna postrojba, koja je došla na Solunsko bojište i borila se u sklopu srbijanske vojske. Sastojala se od 77 dobrovoljaca, od kojih se 9 prijavilo za služenje u pozadini na neborbenim položajima. Stigli su 10. listopada 1917., a sa sobom su donijeli i instrumente za deseteročlani tamburaški zbor. Većina ih se prijavila unutar au- 
DRUŠ. ISTRAŽ. ZAGREB GOD. 21 (2012)

BR. 1 (115)

STR. $239-258$

HRSTIĆ, I.:

POLOŽAJ

DOBROVOLJACA. stralskih logora u kojima su bili internirani, a australske vlasti pomogle su im i opskrbile ih s odijelima te podmirile sve troškove do dolaska u Solun. ${ }^{25}$ Unatoč tome, nakon rata nisu im dopustili povratak u Australiju. ${ }^{26}$

Oni koji su se bili voljni dobrovoljno javiti za služenje u srbijanskoj vojsci bili su i u australskim logorima u manjini, pa su radi svoje sigurnosti morali biti odmah premješteni. ${ }^{27} \mathrm{Iz}$ toga se vidi da, unatoč jakoj agitaciji, ni među hrvatskim iseljenicima u Australiji i Novom Zelandu jugoslavenska ideja nije bila pretjerano popularna, pa napori projugoslavenske struje nisu rezultirali onolikim brojem dobrovoljaca za srbijansku vojsku kojem su se članovi Jugoslavenskog odbora i srbijanske vlade nadali.

\section{DOBROVOLJCI NA SOLUNSKOM BOJIŠTU}

$\longrightarrow$ U jesen 1917. na Solunsko bojište pristigao je i velik broj dobrovoljaca iz Rusije, na što je prestolonasljednik Aleksandar raspustio Vardarsku diviziju te od njezinih članova i dobrovoljaca iz Rusije oformio Jugoslavensku diviziju. Na taj način donekle je udovoljio željama Jugoslavenskog odbora za Jadranskom legijom. Ipak, dobrovoljci iz iseljeništva nisu bili priključeni toj postrojbi. Dolaskom na bojište i dalje su popunjavali redove drugih srbijanskih postrojbi, uz objašnjenje da nisu dovoljno obučeni, a da će se na taj način i najbolje raširiti jugoslavenska ideja među srbijanskom vojskom. ${ }^{28}$

Hrvatski iseljenici javljali su se kao dobrovoljci i za druge vojske, primjerice $u$ američku, australsku, novozelandsku, francusku, a bilo ih je i u sklopu čehoslovačkih postrojbi koje su djelovale u sklopu francuske vojske na Zapadnom bojištu. ${ }^{29}$ Dobrovoljci su regrutirani i iz savezničkih zarobljeničkih logora (Engleska, Francuska, Australija ...). U obraćanju bilo im je naglašeno da je to jedini način da se oslobode, a njihovim je obiteljima bila obećana i financijska pomoć. ${ }^{30}$

\section{POLOŽAJ DOBROVOLJACA}

O položaju dobrovoljaca u srbijanskoj vojsci te odnosu časnika i iskusnijih suboraca prema njima mnogo možemo saznati iz njihove korespondencije s dr. Antom Trumbićem, u kojoj opisuju svoje doživljaje i javljaju mu vijesti s terena. Unatoč javno obećavanoj ravnopravnosti i jednakosti, dobrovoljci su u svakodnevnom životu često bili fizički i verbalno zlostavljani.

Dobrovoljac iz SAD-a, Nikola Radan, preživio je 6. siječnja 1916. brodolom talijanskoga parobroda "Brindisi", koji je prevozio pretežno crnogorske dobrovoljce iz SAD-a. Brod je prilikom ulaska u luku San Giovanni di Medua naišao na podvodnu minu i eksplodirao. ${ }^{31}$ Od otprilike 540 dobrovoljaca preživjelo ih je 145. Radan se sa suborcima po dolasku na Krf 
DRUŠ. ISTRAŽ. ZAGREB GOD. 21 (2012), BR. 1 (115)

STR. $239-258$

HRSTIĆ, I.: POLOŽAJ DOBROVOLJACA sukobio sa srbijanskom vojnom komandom. Tražili su jugoslavenski naziv za svoju postrojbu i nisu se htjeli boriti samo pod srpskim imenom. Na taj zahtjev srbijanska vojna komanda odgovorila je deportacijom 215 dobrovoljaca u lipnju 1916. u više zarobljeničkih logora u Francuskoj. Ondje su ostali zarobljeni i nakon kraja rata. U travnju 1920. su i dalje slali molbe za pomoć pri oslobađanju i neuspješno tražili jugoslavenske putovnice. U isto vrijeme jugoslavensko veleposlanstvo izdavalo je putovnice mnogima koji nisu bili dobrovoljci i za vrijeme rata su odbijali stupiti u vojsku. Dobrovoljci su ondje bili zarobljeni zajedno s njemačkim vojnicima i prema njima se postupalo jednako, a po završetku rata uvjeti su im se minimalno promijenili. Nije ih više čuvala vojska nego civili, za rad su dobivali simboličnu novčanu nadoknadu, a vojni nadglednici dolazili bi u kontrolu tek svakih osam dana. Pedesetak zarobljenika nalazilo se $u$ logoru smještenom u blizini Villefranche de Rouerguea u pokrajini Aveyron, a stotinjak u kartuzijanskom samostanu kraj Le Puya ${ }^{32}$ u pokrajini Gornja Loara. ${ }^{33}$

U zapovijedi od 12. prosinca 1917. godine, Petar Bojović, načelnik štaba vrhovne komande srbijanske vojske, naglasio je da se svi zapovjednici moraju zalagati za potpunu ravnopravnost svih svojih vojnika i suzbijati svaki pokušaj dominacije Srbijanaca ili obratno te da se Hrvatima, Slovencima i Crnogorcima treba dokazati da nema nikakve ideje o prevlasti Srba. ${ }^{34}$ Unatoč toj i sličnim izjavama i zapovijedima, stvarne ravnopravnosti nije bilo, što se vidi i prilikom dolaska dobrovoljaca na bojište te polaganja zakletve. Primjerice, dobrovoljci iz Australije polagali su zakletvu kralju Petru pred pravoslavnim svećenikom, iako su svi bili katoličke vjere. Od toga nisu htjeli praviti veći problem i buniti se, ali su ipak to naglasili u pismu Trumbiću. ${ }^{35} \mathrm{O}$ nepostojanju nacionalne ravnopravnosti svjedoči i insistiranje ministra vojske Mihaila Rašića, koji je pred sam kraj rata, 20. rujna 1918., tražio da prilikom upisivanja u vojsku dobrovoljci daju izjavu o stupanju u "srpsku" vojsku i da se naziv ne mijenja u "jugoslavensku" ili nešto slično. Eventualno, ostavljena je mogućnost da se onome koga izričito smeta samo srpsko ime doda i jugoslavensko u izjavu, ali samo iza srpskog. ${ }^{36}$

Također, bez obzira na zapovijedi o ravnopravnosti svih vojnika i suzbijanja pokušaja dominacije, vojni dočasnici koji su 1918. bili poslani s Krfa u SAD po zadatku prikupljanja i obuke dobrovoljaca imali su instrukcije ministra Rašića da od svih dobrovoljaca, bez obzira na nacionalnost, stvaraju "dobre Srbe". U obrazloženju im je ministar naveo da dobrovoljci time neće ništa izgubiti, a u političkom je interesu srpske vlade. U svom radu trebali su apsolutno slušati zapovijedi Milana 
DRUŠ. ISTRAŽ. ZAGREB GOD. 21 (2012) BR. 1 (115)

STR. $239-258$

HRSTIĆ, I.: POLOŽAJ DOBROVOLJACA..
Pribićevića, pa i onda kada im njegovo djelovanje bude sumnjivo i nerazumljivo, pa čak i štetno, jer je on u direktnom kontaktu s njim i sve što Pribićević radi - radi "u čisto srpskom interesu". Posebno im je naglasio da u dodiru s Hrvatima treba isticati kako oni trebaju biti Srbi, jer će im se tada diviti cijeli svijet. Nakon što se saznalo da su u toj grupi dočasnika bila prisutna i dvojica Hrvata, Rašić ih je pozvao na dodatni razgovor te ih poslao na zadatak u Južnu Ameriku, a ne SAD, kako je ranije namjeravano. Pritom im je i uručio tiskanu Krfsku deklaraciju te naglasio kako srbijanska vlada stoji iza njezinih zaključaka, a zapovijedi po kojima djeluje Pribićević u SAD dane su u dogovoru s Jugoslavenskim odborom, s kojim se dogovaraju sve akcije i bez čijeg se mišljenja ništa ne poduzima. ${ }^{37} \mathrm{No}$, kao što se vidjelo, Jugoslavenski odbor dugo nije znao čak ni za odobravanje francuskog kredita za prikupljanje dobrovoljaca i njihov prijevoz na bojište te upućivanje Pribićevića u Sjevernu, a Poznanovića u Južnu Ameriku po zadatku prikupljanja dobrovoljaca, a isto tako ni za usmene upute koje su srbijanski časnici i dočasnici dobivali prilikom odlaska među iseljenike na agitaciju za srbijansku vojsku. Ovdje se nazire i jedan od razloga zahlađenja odnosa između Milana Pribićevića i srbijanske vlade potkraj rata. Pribićević nije potpuno slijedio njihove naredbe vezane uz odnos prema Hrvatima i Slovencima te je kritizirao takvu vladinu politiku. Prilikom podnošenja molbe za smjenu s položaja šefa misije za skupljanje dobrovoljaca u Sjevernoj Americi, 5. veljače 1918., kao glavni razlog zahtjeva, a i ukupnog neuspjeha misije, navodi se neodlučna jugoslavenska politika Srbije, koja nije uspjela privući Hrvate i Slovence te ih uvjeriti u jedinstvo. ${ }^{38}$

Nezadovoljstvo među dobrovoljcima postojalo je i kod pripadnika Jugoslavenske divizije formirane na Solunskom bojištu potkraj 1917., koju su najvećim dijelom činili dobrovoljci iz Rusije. Časnike dobrovoljce, kojima su vojnici dobrovoljci vjerovali i s kojima su već mnogo bili prošli, zapovjedništvo je premještalo $u$ druge divizije srbijanske vojske, unatoč tome što su se i oni i vojnici zalagali za njihov zajednički ostanak u istoj postrojbi. Dobrovoljci su smatrali da časnici koji dolaze na njihovo mjesto ne odgovaraju njihovim navikama. ${ }^{39}$ Stvaranje ove postrojbe trebalo je poslužiti Jugoslavenskom odboru i svim dobrovoljcima kao dokaz da ih se ne želi "utopiti" u srbijansku vojsku. No u nju su se kasnije priključivali i redoviti srbijanski vojnici, koji su često vrijeđali narodne svetinje zbog kojih su dobrovoljci došli u rat. Svojim ponašanjem pogubno su djelovali na moral dobrovoljaca te su s njima ulazili u sukobe. ${ }^{40} \mathrm{Za}$ to vrijeme manje grupe dobrovoljaca iz inozemstva raspoređivane su po ostalim postrojbama. Naglašavalo se da su jedini razlozi tomu njihova nedovoljna oprem- 
DRUŠ. ISTRAŽ. ZAGREB GOD. 21 (2012), BR. 1 (115)

STR. $239-258$

HRSTIĆ, I.: POLOŽAJ DOBROVOLJACA ljenost i uvježbanost te želja da se na taj način upozna dobrovoljce sa starijim srbijanskim borcima i na taj način u cijeloj vojsci ojača jugoslavenski duh i zanos, koji dobrovoljci sa sobom donose. ${ }^{41}$

Časnicima i srbijanskim vojnicima bilo je posebno zabranjeno fizičko kažnjavanje i upotreba psovki pri ophođenju s dobrovoljcima. ${ }^{42}$ No ni te se naredbe nisu dosljedno poštovale i izvršavale, pa se loše ponašanje prema dobrovoljcima prakticiralo i dalje. Primjerice, dobrovoljca 2. čete 3. bataljuna $\mathrm{XV}$. pješadijske pukovnije psovao je i istukao njegov vodnik, poručnik Jovan Jovanović, a dobrovoljca Stjepana Starčevića časnik je počeo vrijeđati i tući pošto ga nije pozdravio. ${ }^{43}$ Starčević je uzvratio udarac, a vojni sud ga je zbog toga osudio na zatvorsku kaznu u Skopju, gdje je bio zatvoren s drugim dobrovoljcima koji su ondje boravili zbog sličnih prijestupa. Po Starčevićevu svjedočenju, u zatvoru su bili goli, bosi i gnjavnjeni sa svakijem neredom. U svojoj molbi za pomoć, upućenoj dr. Trumbiću 21. listopada 1919., nakon već osam mjeseci provedenih $\mathrm{u}$ zatvoru, navodi da su dobrovoljci često stradali $\mathrm{u}$ raznim sukobima unutar vojske. 44 Žrtve sličnih maltretiranja bili su najčešće dobrovoljci podrijetlom iz Crne Gore, kojima su se vojnici osvećivali za brojne neugodnosti koje su doživjeli tijekom povlačenja kroz Crnu Goru od lokalnoga stanovništva, ali nisu bili pošteđeni ni dobrovoljci drugih nacija. ${ }^{45}$

Druga grupa dobrovoljaca podnosila je duže vrijeme mnoga omalovažavanja, maltretiranja, nazivanja "Švabama", batinanja i psovanja. Po povratku sa Solunskoga bojišta u Bizertu, u drugoj polovici 1916., nekolicina ih se pobunila i otkazala poslušnost te odbila vratiti se na bojište. Pošto je dio dobrovoljaca odbio poslušnost, cijela grupa, njih 80 , odmah je zatvorena u dvije vlažne barake pune buha. Iz njih nisu smjeli izlaziti, a bili su bez hrane, pokrivača i osnovnih potrepština. Časnici su im stalno prijetili strijeljanjem, na što su ovi odgovarali neka ih samo strijeljaju jer se ne boje smrti. Strijeljaj! Ne bojim se ja smrti, mi smo sa svih strana pohrlili da vam pomognemo, ja sam došao iz Rusije. Ovaj iz Amerike o svom trošku. Onaj otale, onaj otalen, a vi ste nas dočekali batinama, psovkom, nepravdom $i$ svakojakim zlom, a ne ljubavlju. Stariji suborci su ih konstantno optuživali da su došli u srbijansku vojsku samo najesti se kruha i njima je toga bilo dosta: "...dajte vi vaš leb i batine drugima nama ne treba ni jedno ni drugo." Nisu htjeli da ih se više ni u šali naziva Srbima, što im je ranije bio običaj, a u svojoj žalbi Jugoslavenskom odboru spominju i više ubijenih dobrovoljaca. Među njima posebno izdvajaju ubojstvo dobrovoljca narednika Delića, o čemu je pokrenuta istraga tek nakon što su se njegovi suborci, drugi dobrovoljci, potužili Francuzima. ${ }^{46} \mathrm{O}$ uvjetima u kojima su dobrovoljci živjeli svje- 
DRUŠ. ISTRAŽ. ZAGREB GOD. 21 (2012)

BR. 1 (115),

STR. $239-258$

HRSTIĆ, I.:

POLOŽAJ

DOBROVOLJACA. doče i pokušaji bijega više dobrovoljaca iz Dunavske divizije. ${ }^{47}$

Dobrovoljce koji su odbijali ostanak u borbenim linijama divizijski je vojni sud zatvarao u logore i osuđivao na prisilni rad u rudnicima zajedno s neprijateljima, gdje su bili tretirani kao svi drugi zarobljenici koji nisu bili srbijanski državljani te su im oduzimana dobrovoljačka beriva i obećane nagrade. 48 Izlazak iz vojske nije bio moguć, a bjeguncima se sudilo po vojnom zakonu. Vrhovna komanda zadržala je pravo odlučivanja o pojedinačnim zahtjevima za premještaj u neborbene postrojbe, a u pokušaju da napuste vojsku neki dobrovoljci obraćali su se molbama i Jugoslavenskom odboru. ${ }^{49}$ Tražili su da se njegovi predstavnici založe kod Vrhovne komande srbijanske vojske i omoguće im odlazak kućama i obiteljima koje su morali uzdržavati. ${ }^{50}$ Sve takve molbe su na kraju odbijane s obrazloženjem da su dobrovoljci dali pismeni pristanak prilikom prijavljivanja i da izlazak iz vojske nije u skladu s tim. U slučajevima kada bi dobrovoljci nastavili s traženjem otpusta i pritom prijetili da će u suprotnom prestati izvršavati svoje vojne obveze podlijegali su presudi vojnog suda, koji je bio nemilosrdan. 51

Po završetku rata dobrovoljci su bili dodatno razočarani odnosom vlade i vojske prema njima. ${ }^{52}$ Nakon demobilizacije praktički im je onemogućen bilo kakav daljnji politički i društveni utjecaj (Leontić, 1960., 80). Nakon povratka kući nisu mogli naći posao niti dobiti potporu lokalne vlasti, koja ih je upućivala na one koji su ih uopće zvali u rat. ${ }^{53}$ Dodjeljivanje obećane im zemlje za dobrovoljno služenje $u$ vojsci odugovlačilo se, a mnogi su bili primorani vratiti se u zemlje odakle su došli. ${ }^{54}$ U ožujku 1920. stigla su u New York parobrodom 694 bivša dobrovoljca. U njihovoj pratnji bilo je i 56 žena te 10 djece, koji su na polazak čekali nekoliko mjeseci u Dubrovniku. U New Yorku ih nitko nije dočekao, jer iz Kraljevine nije nitko ni javio da stižu. Primio ih je Crveni križ i pružio im osnovnu pomoć pri dolasku. Bili su bez novca i u teškom stanju, a Crveni križ je uspio pronaći posao za njih 300 u Pittsburghu te nekolicini po rudnicima u Pennsylvaniji i Zapadnoj Virginiji. Ostatak je privremeno smjestio u New Yorku, gdje su im osigurali hranu, smještaj i odjeću. ${ }^{55}$ Tako su, "kao prosjaci", vraćeni u SAD u puno težim uvjetima nego kad su odlazili u rat.

Potrebno je naglasiti i da je među dobrovoljcima bilo onih koji nisu imali nikakvih problema sa Srbima te su svjedočili o izvanrednom poštovanju i suradnji sa svima. Ipak, na primjeru Ivana Čovića, dobrovoljca iz SAD-a, vidi se da unatoč njegovim najljepšim riječima o prihvaćanju, u svakodnevici se držao uskoga kruga dobrovoljaca i prijatelja s koji- 
DRUŠ. ISTRAŽ. ZAGREB GOD. 21 (2012), BR. 1 (115)

STR. $239-258$

HRSTIĆ, I.: POLOŽAJ DOBROVOLJACA ma je došao iz SAD-a u vojsku. ${ }^{56} \mathrm{~S}$ njima je bio zajedno u četi i od njih se nikad nije odvajao, pa do prave integracije sa starijim suborcima nije došlo. Čak su odbijali i ići na zadatke koji su tražili od njih da se razdvoje. O sličnom ponašanju ostalih dobrovoljaca svjedoče i izvještaji njihovih zapovjednika u kojima ističu da su se dobrovoljci izvan službe odmah grupirali po regionalnoj i nacionalnoj osnovi. ${ }^{57}$ Time je propala i nakana srbijanske vrhovne komande o uvođenju dobrovoljaca iz iseljeništva među postojeće postrojbe, kako bi se jačao jugoslavenski duh kod Srbijanaca.

\section{ZAKLJUČAK}

Tijekom Prvog svjetskog rata u srbijansku vojsku dobrovoljno je stupilo oko 10000 južnoslavenskih iseljenika, među kojima nekoliko stotina Hrvata iz SAD-a, Australije, Novog Zelanda te Južne Amerike. Srbijanska vlada i vojska vodili su prema njima dvostruku politiku. Dugo su bili protiv njihova velikog broja u vojsci, pogotovo Hrvata i Slovenaca te jugoslavenski orijentiranih Srba, no nakon katastrofalnih poraza i gubitaka počeli su više raditi na njihovu privlačenju. U obraćanju iseljenicima, Jugoslavenskom odboru i javnosti općenito obećavali su ravnopravnost $\mathrm{i}$ jednakost svima. U zapovijedima svojim časnicima i vojnicima tražili su od njih isto, ali u stvarnosti se te zapovijedi nisu provodile $u$ djelo. Od svih njih htjeli su "napraviti dobre Srbe", kako je to rekao srbijanski ministar vojske Mihailo Rašić. Uzevši to u obzir, na brojna kršenja zapovijedi i zlostavljanja dobrovoljaca teško se može gledati kao na pojedinačne incidente. Osobito zato što je vojska prilikom izvršavanja svih ostalih zapovijedi bila vrlo disciplinirana, a kazne za bilo kakvo oglušivanje o njih u svim drugim slučajevima bile su izrazito rigorozne.

Dobrovoljci koji su reagirali na zlostavljanja bili su zatvarani u zatvore i logore, oduzimane su im obećane dobrovoljačke nagrade i beriva, a izlazak iz vojske bio im je onemogućen. Unatoč svemu, većina dobrovoljaca davala je sve od sebe da dokaže vjernost "zajedničkoj stvari", što najbolje pokazuju i pohvale nadređenih za ponašanje $u$ borbi i izvršavanje svih zadataka. Zbog svega toga dobrovoljci su se uglavnom družili samo međusobno, pa time nije postignuto ni obrazloženje njihova uklapanja u postojeće postrojbe, a to je da oni šire jugoslavenske ideje buduće zajedničke države među Srbijancima.

O odnosu prema njima možda najbolje govori i povratak velike grupe dobrovoljaca nakon rata u SAD, kada su se kao siromasi morali obratiti Crvenom križu za pomoć. Iako su nedugo prije toga prešli pola svijeta da stupe u vojsku i bili spremni dati svoj život za buduću zajedničku državu i jugoslavensku ideju, nakon završetka rata ostali su razočarani i izdani. 
1 Fond se naziva još i "Arhiv Jugoslavenskog odbora", no uobičajeniji naziv u literaturi jest "Arhiv dr. Ante Trumbića", pa se stoga rabi i u ovom radu. Jugoslavenski odbor službeno je osnovan 30. travnja u Parizu, a djelovao je u Londonu te prestao s djelovanjem 2. lipnja 1919. u Zagrebu. Bogata knjižnica i Arhiv bili su do 1922. smješteni u podrumu Sveučilišne knjižnice u Zagrebu, a 22. lipnja 1922. premješteni su u stan dr. Ante Trumbića u Zagrebu, gdje su se nalazili do njegove smrti, 18. rujna 1938. Trumbić je svu imovinu Jugoslavenskog odbora oporučno ostavio na čuvanje Jugoslavenskoj akademiji znanosti i umjetnosti u Zagrebu. Ovaj arhivski fond danas je jedan od najvećih fondova HAZU-a i sadrži više od 160 kutija, omota i svežnjeva raznih memoranduma, proglasa, originalnih zapisnika sa sjednica Odbora, dopisivanje Odbora s iseljenicima, pisma članova Odbora, raznih propagandnih materijala, slike, novinske isječke i druge materijale. Najveći dio čini građa nastala između 1914. i 1919., a Trumbićeve bilješke idu sve do 1938.

2 Ljubo Leontić - pravnik, publicist i političar. U Austro-Ugarskoj Monarhiji bio je pripadnik nacionalističke omladine te se zalagao za ujedinjenje južnoslavenskih naroda unutar Monarhije s Kraljevinom Srbijom. Nakon početka Prvog svjetskog rata emigrirao je u Italiju, a tijekom rata bio je aktivan među hrvatskim iseljenicima u Južnoj i Sjevernoj Americi kao član Jugoslavenskog odbora i predstavnik Jugoslavenske nacionalističke omladine. Usporedi: Hrvatska enciklopedija, Leontić Ljubo, 2004., sv. 6, 513.

3 Arhiv Hrvatske akademije znanosti i umjetnosti, Zagreb (dalje: AHAZU), Arhiv dr. Ante Trumbića (dalje: ADAT), 45/221, Pismo dr. Ante Trumbića kraljevskom poslanstvu Kraljevine Srbije u Rimu od 23. veljače 1915.

4 Milan Marjanović - jedan od osnivača Jugoslavenskog odbora. Izdavao je Southern Slav Bulletin, glasnik Odbora. Potkraj 1915. boravio je kao izaslanik Jugoslavenskog odbora u SAD-u. Sredinom 1917. otišao je u Južnu Ameriku, gdje je pokrenuo časopis Obnova. Poslije rata bio je član mirovne delegacije Kraljevine SHS u Parizu. Usporedi: Opća enciklopedija jugoslavenskog leksikografskog zavoda, Milan Marjanović, 1979., sv. 5, 328; Ujević, M. (1965.), Milan Marjanović, Enciklopedija Jugoslavije, sv. 6, 20.

${ }^{5}$ Miće Mičić - političar. Kao član Jugoslavenskog odbora agitirao je među iseljenicima u Južnoj i Sjevernoj Americi te diljem Europe. Bio je jedan od utemeljitelja Jugoslavenske narodne obrane u Južnoj Americi.

$6 \mathrm{U}$ ovom radu obrađuju se dobrovoljci iz iseljeništva, a za više o dobrovoljcima u Rusiji usporedi: Jovanović, I., Rajković, S., Rib, V. (prir.) (1954.), Jugoslovenski dobrovoljački korpus u Rusiji: prilog istoriji dobrovoljačkog pokreta 1914.-1918., Beograd, Vojno delo; Kostić, Ž. (1959.), Dobrovoljci, Vojna enciklopedija, sv. 2, Beograd, 495-499; Lazarević, B. (1919.), Jugoslavenski dokumenti - pregled narodnog pokreta u domovini $i$ inostranstvu za vreme svetskog rata, Zagreb; Popović, N. (prir.) (1977.), Jugoslovenski dobrovoljci u Rusiji 1914.-1918., Beograd, Udruženje dobrovoljaca 1912.-1918.; Popović, N. (prir.) (1980.), Jugoslovenski dobrovoljci 1914.-1918., Beograd, Udruženje dobrovoljaca 1912.-1918.; Potočnjak, F. (1919.a), Iz emigracije, sv. I, Zagreb, U komisiji knjižare M. Breyera; Potočnjak, F. (1919.b), Iz emigracije, sv. II, Zagreb, U komisiji 
DRUŠ. ISTRAŽ. ZAGREB GOD. 21 (2012), BR. 1 (115) STR. $239-258$

HRSTIĆ, I.: POLOŽAJ DOBROVOLJACA knjižare M. Breyera; Potočnjak, F. (1926.), Iz emigracije, sv. III, Zagreb, U komisiji knjižare M. Breyera; Slijepčević, P. (1925.), Naši dobrovoljci u svetskom ratu, Zagreb, Grafičko-nakladni zavod.

7 Franko Potočnjak - političar i publicist. Na početku 1915. boravio je u SAD-u uime Jugoslavenskog odbora, gdje je agitirao među iseljenicima za potporu ideji ujedinjenja južnoslavenskih naroda unutar Monarhije s Kraljevinom Srbijom te je pokrenuo akciju prikupljanja dobrovoljaca. U Chicagu je 10.-11. ožujka 1915. organizirao prvi zbor južnoslavenskih iseljeničkih društava. U Rusiji je 1916. bio aktivan među dobrovoljcima u Odesi, a sudjelovao je i na Krfskoj konferenciji 1917. Usporedi: Šepić, D. (1965.), Potočnjak Franko, Enciklopedija Jugoslavije, sv. 6, 574-575.

8 Milan Pribićević - bivši časnik austrougarske vojske, koji je prešao u Srbiju 1904. Nakon Prvog svjetskog rata bio je šef srpske vojne misije u Zagrebu. Napustio je vojsku 1919. te se posvetio politici. Usporedi: Matković, H. (1965.), Milan Pribićević, Enciklopedija Jugoslavije, sv. 6,611 .

9 Vlada Kraljevine Srbije donijela je odluku o dodjeljivanju zemlje dobrovoljcima iz Amerike na sjednici održanoj na Krfu 27. listopada 1916., a dopunila ju je 17. veljače 1918. odlukom da pravo na zemlju imaju svi dobrovoljci bez obzira odakle dolazili. Usporedi: Godišnjak o radu Ministarstva socijalne politike u godini 1918.-1921., Zagreb 1922., 43; Rašić, M., "Uput za prijem dobrovoljaca Jugoslovena u srpsku vojsku; uslovi, odredbe, rešenja i naređenja", Jugoslovenski dobrovoljci 1914.-1918., 136.

10 Usporedi: Leontić, Lj. (1960.), O Jugoslovenskom odboru u Londonu, Starine, 50, 5-169.

11 AHAZU, ADAT, 42/58, Pismo Miće Mičića Jugoslavenskom odboru od 16. rujna 1915.; AHAZU, ADAT, 42/59, Pismo Miće Mičića Jugoslavenskom odboru od 4. listopada 1915.; AHAZU, ADAT, 42/67, Pismo Miće Mičića Jugoslavenskom odboru od 27. studenog 1915.

12 Više o ovom proglasu te njegovim posljedicama usporedi: Hameršak, F. (2005.), Josip Jedlowski - životopis (s bilješkama za transnacionalnu povijest jedne građanske obitelji), Časopis za suvremenu povijest, 37 (1): 101-127.

13 Primjerice, u Čileu se do siječnja 1917. za Jadransku legiju prijavilo 475 dobrovoljaca. Usporedi: Leontić, Lj. (1960.), O Jugoslovenskom odboru u Londonu, Starine, 50, 84; AHAZU, ADAT, 45/64, Pismo Miće Mičića dr. Anti Trumbiću od 15. ožujka 1917.

14 AHAZU, ADAT, 84/3 (64), Zapisnik sjednice Jugoslavenskog odbora održane u Nici 10. veljače 1917.

15 AHAZU, ADAT, 84/3 (65), Zapisnik sjednice Jugoslavenskog odbora održane u Cannesu 21. veljače 1917.

16 AHAZU, ADAT, 28/12, Pismo dr. Bakotića, kraljevskoga srbijanskog poslanika u Rimu, dr. Anti Trumbiću od 8. prosinca 1917.

17 AHAZU, ADAT, 28/88 (1-36), Dobrovoljački upisni listovi za Jadransku legiju.

18 AHAZU, ADAT, 42/9, Izvještaj Milana Marjanovića Jugoslavenskom odboru o situaciji u SAD-u od 22. kolovoza 1916. 
DRUŠ. ISTRAŽ. ZAGREB GOD. 21 (2012) BR. 1 (115)

STR. 239-258

HRSTIĆ, I.: POLOŽAJ DOBROVOLJACA.
${ }_{19}$ Prvi jugoslavenski zbor u SAD-u održan je u Chicagu 10. i 11. ožujka 1915., ali na njemu nije bilo riječi o dobrovoljcima.

20 AHAZU, ADAT, 16/27 (1), Jugoslovenski bulletin, br. 1 od 24. ožujka 1917.; AHAZU, ADAT, 16/27 (2), Jugoslovenski bulletin, br. 2 od 31. ožujka 1917.; AHAZU, ADAT, 42/4, Pismo Milana Marjanovića Jugoslavenskom odboru od 7. prosinca 1916.

21 AHAZU, ADAT, 122/24, Proglas Jugoslavenskog sokolskog saveza u SAD-u.

22 AHAZU, ADAT, 42/2, Izvještaj Milana Marjanovića o djelovanju Srpskog dnevnika te jugoslavenskom pokretu i Hrvatima u SAD-u; AHAZU, ADAT, 42/9, Izvještaj Milana Marjanovića Jugoslavenskom odboru o situaciji u SAD-u od 22. kolovoza 1916.; AHAZU, ADAT, 122/25, Izvještaj Milana Marjanovića i dr. Nikole Županića Jugoslavenskom odboru o situaciji u SAD-u od 22. rujna 1916.

23 Pribićević, M., M. Pribićević - vojnom izaslaniku Srbije kod Francuske vrhovne komande; Janković, D., Krizman, B. (prir.) (1964.), Građa o stvaranju jugoslovenske države (1. I.-20. XII. 1918.), Beograd, 85.

${ }^{24}$ AHAZU, ADAT, 53/2, Memorandum Hinka Hinkovića kraljevskom srbijanskom poslanstvu o jugoslavenskoj koloniji u Novom Zelandu od 11. listopada 1916.

25 Atanasijević, Ž., "Izveštaj br. 43060 dopunske komande srpskoj Vrhovnoj komandi, za Operativno odeljenje", Jugoslovenski dobrovoljci 1914.-1918., 316-317.

26 Atanasijević, Ž., "Izveštaj br. 43060 dopunske komande srpskoj Vrhovnoj komandi, za Operativno odeljenje", Jugoslovenski dobrovoljci 1914.-1918., 202.

27 AHAZU, ADAT, 46/87, Pismo Stjepana Pećara Jugoslavenskom odboru od 28. kolovoza 1917.

28 Bojović, P., "Pismo Obr. 17304 štaba Vrhovne komande srpskom Ministarstvu vojnom", Jugoslovenski dobrovoljci 1914.-1918., 376-378.

${ }^{29}$ AHAZU, ADAT, 28/99, Pismo Ivana Borića dr. Anti Trumbiću od 17. travnja 1919.; AHAZU, ADAT, 28/134, Pismo M. Bebicha dr. Anti Trumbiću od 22. veljače 1919.; AHAZU, ADAT, 99/30, Pismo Jure Stelle Jugoslavenskom odboru od 22. srpnja 1917.; AHAZU, ADAT, 99/33, Popis jugoslavenskih dobrovoljaca za australsku vojsku; AHAZU, ADAT, 102/17, Popis dalmatinskih dobrovoljaca u novozelandskoj vojsci; AHAZU, ADAT, 108/176, Pismo Huga Stipanovića Jugoslavenskom odboru.

30 AHAZU, ADAT, 7/3, Pismo Josipa Jedlowskog interniranim Jugoslavenima $\mathrm{u}$ engleskom logoru na nepoznatoj lokaciji od 24. kolovoza 1916.; AHAZU, ADAT, 45/107, Pismo Jugoslavenskog odbora vojnom izaslaniku Kraljevine Srbije u Londonu Milivoju Nikolajeviću od 8. prosinca 1916.; AHAZU, ADAT, 45/110 (3), Pismo Jugoslavenskog odbora vojnom izaslaniku Kraljevine Srbije u Londonu Milivoju Nikolajeviću od 22. siječnja 1917.; AHAZU, ADAT, 46/114, Pismo Slavka Paulića Jugoslavenskom odboru od 12. siječnja 1917.; AHAZU, ADAT, 118/113, Pismo Jugoslavenskog odbora J. Verboi od 22. studenog 1918.; AHAZU, ADAT, 118/119, Pismo Jugoslavenskog odbora Ivanu Čoviću od 6. listopada 1917. 
DRUŠ. ISTRAŽ. ZAGREB GOD. 21 (2012), BR. 1 (115) STR. 239-258

HRSTIĆ, I.: POLOŽAJ DOBROVOLJACA
31 Danas grad Shëngjin na sjeveroistoku Albanije, a u literaturi se navodi i kao Medova.

32 Danas grad Le Puy-en-Velay.

33 AHAZU, ADAT, 7/5, Pismo Pere Slijepčevića dr. Anti Trumbiću od 5. travnja 1919.

34 Bojović, P., "Naredba Obr. 20776 đenerala Petra Bojovića, načelnika štaba srpske Vrhovne komande za sve trupe i ustanove za 12. decembar 1917. godine", Jugoslovenski dobrovoljci 1914.-1918., 386-388.

35 AHAZU, ADAT, 118/124, Pismo Čedomira Bušelića Jugoslavenskom odboru od 23. veljače 1918.

36 Rašić, M., "Pismo pov. FBObr. srpskog Ministarstva vojnog srpskom ministru inostranih poslova", Jugoslovenski dobrovoljci 1914.-1918., 397-398.

37 AHAZU, ADAT, 46/46 (1), Pismo Mirka Pećara dr. Anti Trumbiću od 25. ožujka 1918.; AHAZU, ADAT, 46/46 (2), Pismo Lovre (nepoznato prezime) dr. Anti Trumbiću od 30. ožujka 1918.

38 Pribićević, M., "Izveštaj potpukovnika Milana Pribićevića o svom radu u Americi od decembra 1916. do marta 1917., Vašington, 15. III. 1917.", Jugoslovenski dobrovoljci 1914.-1918., 169.

39 AHAZU, ADAT, 28/19, Izvještaj nepoznatog autora o prilikama u Jugoslavenskoj diviziji na Solunskom frontu.

40 AHAZU, ADAT, 28/19, Izvještaj nepoznatog autora o prilikama u Jugoslavenskoj diviziji na Solunskom frontu.

41 Bojović, P., "Pismo Obr. 17304 štaba srpske Vrhovne komande srpskom Ministarstvu vojnom", Jugoslovenski dobrovoljci 1914.-1918., 376-377.

42 AHAZU, ADAT, 28/21, Naredba generala Petra Bojovića, načelnika štaba srbijanske vojske, za 29. studeni 1917.; Bojović, P., "Naredba Obr. 20776 đenerala Petra Bojovića, načelnika štaba srpske Vrhovne komande za sve trupe i ustanove za 12. decembar 1917. godine", Jugoslovenski dobrovoljci 1914.-1918., 386-388.

43 Zečević, M., "Naredba Obr. 8428 pukovnika Mih. Zečevića, komandanta Timočke divizije za 25. decembar 1917. godine", Jugoslovenski dobrovoljci 1914.-1918., 388-391.

44 AHAZU, ADAT, 28/96, Pismo Stjepana Starčevića dr. Anti Trumbiću od 21. listopada 1919.

45 Terzić, B., "Pismo pov. FBObr. 4383 srpskog Ministarstva vojnog srpskoj Vrhovnoj komandi", Jugoslovenski dobrovoljci 1914.-1918., 373.

46 AHAZU, ADAT, 28/98, Pismo Dragišića (nepoznato ime) dr. Anti Trumbiću od 1. studenog 1916.

47 AHAZU, ADAT, 28/33, Dopis zapovjednika Dunavske divizije Svet. Matića zapovjedniku Prve armije od 24. srpnja 1917.

48 AHAZU, ADAT, 28/19, Izvještaj nepoznatog autora o prilikama u Jugoslavenskoj diviziji na Solunskom frontu; AHAZU, ADAT, 28/24, Naredba generala Petra Bojovića, načelnika štaba srbijanske vojske od 26. listopada 1918.; AHAZU, ADAT, 28/33, Naredba generala Petra Bojovića, načelnika štaba srbijanske vojske od 16. lipnja 1918.

49 AHAZU, ADAT, 28/33a, Naredba generala Petra Bojovića, načelnika štaba srbijanske vojske od 9. kolovoza 1918. 
DRUŠ. ISTRAŽ. ZAGREB GOD. 21 (2012)

BR. 1 (115),

STR. 239-258

HRSTIĆ, I.:

POLOŽAJ

DOBROVOLJACA.
50 AHAZU, ADAT, 28/90, Pismo Veljka Rusana dr. Anti Trumbiću od 19. listopada 1918.

51 AHAZU, ADAT, 28/33a, Naredba generala Petra Bojovića, načelnika štaba srbijanske vojske od 9. kolovoza 1918.

52 "Polazak legionaša u Ameriku", Novo Doba (Split), br. 45, 24. 02. 1920., 3.

53 "Stanje naših dobrovoljaca", Zastava (Split), br. 16, 24. 07. 1919., 1.

54 "Dobrovoljačko pitanje", Primorski glasnik (Split), br. 23, 4. 03. 1922., 3; "Iseljeničko pitanje", Novo Doba (Split), br. 37, 14. 02. 1920., 2; "Legionaši sa solunskog fronta", Novo Doba (Split), br. 288, 21. 12. 1921., 3; AHAZU, ADAT, 60/26, Pismo Gjure Matutinovića dr. Josipu Smodlaki od 17. rujna 1919.

55 AHAZU, ADAT, 16/60, Izvještaj Američkog Crvenog križa o jugoslavenskim dobrovoljcima pristiglima u SAD.

56 Usporedi: Hrstić, I. (2010.), Dnevnik Ivana Čovića - prilog istraživanju dobrovoljačkog pokreta među Hrvatima u SAD-u u vrijeme Prvoga svjetskog rata, Ćasopis za suvremenu povijest, 42 (1), 157-177.

57 Kalafatović, D., "Pismo Obr. 19126 štaba srpske Vrhovne komande komandantu I. Armije", Jugoslovenski dobrovoljci 1914.-1918., 383.

\section{IZVORI}

\section{NEOBJAVLJENA GRAĐA}

Arhiv Hrvatske akademije znanosti i umjetnosti u Zagrebu, Arhiv dr. Ante Trumbića.

\section{OBJAVLJENA GRAĐA}

Godišnjak o radu Ministarstva socijalne politike u godini 1918.-1921., Zagreb 1922.

Janković, D., Krizman, B. (prir.) (1964.), Građa o stvaranju jugoslovenske države (1. I.-20. XII. 1918.), Beograd.

Jovanović, I., Rajković, S., Rib, V. (prir.) (1954.), Jugoslovenski dobrovoljački korpus u Rusiji: prilog istoriji dobrovoljačkog pokreta 1914.-1918., Beograd, Vojno delo.

Lazarević, B. (1919.), Jugoslavenski dokumenti - pregled narodnog pokreta $u$ domovini i inostranstou za vreme svetskog rata, Zagreb.

Popović, N. (prir.) (1977.), Jugoslovenski dobrovoljci u Rusiji 1914.-1918., Beograd, Udruženje dobrovoljaca 1912.-1918.

Popović, N. (prir.) (1980.), Jugoslovenski dobrovoljci 1914.-1918., Beograd, Udruženje dobrovoljaca 1912.-1918.

\section{LITERATURA}

Čizmić, I. (1974.), Jugoslavenski iseljenički pokret u SAD $i$ stvaranje jugoslavenske države 1918., Zagreb, Sveučilište u Zagrebu - Institut za hrvatsku povijest.

Čizmić, I. (1981.), Iz Dalmacije u Novi Zeland: povijest jugoslavenske naseobine na Novom Zelandu, Zagreb, Matica iseljenika Hrvatske. 
DRUŠ. ISTRAŽ. ZAGREB GOD. 21 (2012), BR. 1 (115)

STR. 239-258

HRSTIĆ, I.: POLOŽAJ DOBROVOLJACA
Hameršak, F. (2005.), Josip Jedlowski - životopis (s bilješkama za transnacionalnu povijest jedne građanske obitelji). Časopis za suvremenu povijest, 37 (1): 101-127.

Holjevac, V. (1968.), Hrvati izvan domovine, Zagreb, Matica Hrvatska.

Hrstić, I. (2010.), Dnevnik Ivana Čovića - prilog istraživanju dobrovoljačkog pokreta među Hrvatima u SAD-u u vrijeme Prvoga svjetskog rata. Časopis za suvremenu povijest, 42 (1): 157-177.

Hrvatska enciklopedija, Leontić Ljubo, 2004., sv. 6, 513.

Kolin, M. (1920.), Jugosloveni u Južnoj Americi u radu za svoj narod, Zagreb.

Kostić, Ž. (1959.), Dobrovoljci, Vojna enciklopedija, sv. 2, Beograd, 495-499. Leontić, Lj. (1960.), O Jugoslovenskom odboru u Londonu. Starine, 50: 5-169.

Leontić, Lj. (1966.), Jugoslovenski odbor u Londonu i Jugoslovenska omladina. U: V. Bogdanov, F. Čulinović i M. Kostrenčić (ur.), Jugoslavenski odbor u Londonu: u povodu 50 - godišnjice osnivanja, Zagreb, Jugoslavenska akademija znanosti i umjetnosti.

Matković, H. (1965.), Milan Pribićević, Enciklopedija Jugoslavije, sv. 6, 611.

Opća enciklopedija jugoslavenskog leksikografskog zavoda, Milan Marjanović, 1979., sv. 5., 328.

Paulova, M. (1925.), Jugoslavenski odbor: (povijest jugoslavenske emigracije za svjetskog rata od 1914-1918), Zagreb, Prosvjetna nakladna zadruga.

Potočnjak, F. (1919.a), Iz emigracije, sv. I, Zagreb, U komisiji knjižare M. Breyera.

Potočnjak, F. (1919.b), Iz emigracije, sv. II, Zagreb, U komisiji knjižare M. Breyera.

Potočnjak, F. (1926.), Iz emigracije, sv. III, Zagreb, U komisiji knjižare M. Breyera.

Slijepčević, P. (1925.), Naši dobrovoljci u svetskom ratu, Zagreb, Grafičko-nakladni zavod.

Stenning, M. (1995.), Austrian Slavs Internment Camps of Australia World War I, Sydney, N. S. W.

Šepić, D. (1965.), Potočnjak Franko, Enciklopedija Jugoslavije, sv. 6, 574-575. Šutalo, I. (2004.), Croatians in Australia: Pioneers, Settlers and Their Descendants, Kent Town, Wakefield Press.

Ujević, M. (1965.), Milan Marjanović, Enciklopedija Jugoslavije, sv. 6, 20. 
DRUŠ. ISTRAŽ. ZAGREB GOD. 21 (2012)

BR. 1 (115),

STR. $239-258$

HRSTIĆ, I.:

POLOŽA

DOBROVOLJACA...
Position of Emigrant Volunteers in the Serbian Army According to Documents from the Ante Trumbić Archives (1914 - 1918)

Ivan HRSTIĆ

Institute of Social Sciences Ivo Pilar, Zagreb

In this paper the volunteer movement among Croatian emigrants for the Serbian Army in World War I as well as their status in the army have been analysed using the documents from the Archive of dr. Ante Trumbic kept at the Croatian Academy of Sciences and Arts in Zagreb. Most of the volunteers came from North and South America,

Australia and New Zealand. They joined the army on the Salonika front, where they were incorporated into already existing units, despite the effort of the Yugoslav Committee to create a special unit that would symbolize the political will of Southern Slavs in the Austro-Hungarian Monarchy for unification with the Kingdom of Serbia. The Serbian government and the army had a dual policy on volunteers. Publicly, they proclaimed equality for all soldiers and volunteers and at the same time the officers that were sent abroad for agitation were instructed secretly to convert Croats to "good Serbs". The Yugoslav Committee was ignorant of the activities involving recruitment of the volunteers and their situation in the army, where they were often ill-treated. When the volunteers reacted to maltreatment, they were harshly confined. After the War, a great number of them returned to the countries they came from.

Keywords: emigration, World War I, volunteer movement, Yugoslav Committee, Serbian Army 